\title{
Combined deficiency of iron and vitamin D in Asian toddlers
}

\author{
H GRINDULIS, P H SCOTT, N R BELTON, AND B A WHARTON
}

Sorrento Maternity Hospital, Birmingham, and Department of Child Life and Health, Edinburgh

SUMmary One hundred and forty five Asian children born at Sorrento Maternity Hospital, Birmingham, were reviewed at the age of 22 months. A significant association of iron deficiency and poor vitamin D state was found. Two fifths of the children were anaemic, two fifths had a low plasma concentration of vitamin $\mathrm{D}$, and one fifth had both features. This was more than simple overlap of the two deficiencies; the children with low plasma vitamin $\mathrm{D}$ concentrations had significantly lower concentrations of haemoglobin and serum iron. On the other hand, the deficiencies were not merely individual features of generally poor nutrition; growth and other measures of protein energy nutrition were slightly better in these children, and their plasma zinc concentration was no lower than in the children without deficiencies. It seems, therefore, that child health surveillance as currently practised-for example, growth monitoring, clinical signs, etc-will not detect these problems unless a haemoglobin determination is included. In view of the association of poor iron and vitamin D state combined prophylaxis is desirable. At present, strategies for preventing rickets in this country are not combined with attempts to detect or prevent iron deficiency. In our opinion they should be and the options are discussed.

Many aspects of infant feeding have improved since the publication of Present Day Practice in Infant Feeding in $1974,{ }^{1}$ but there are still some areas of concern, and one of these, voiced in the subsequent report in $1980,{ }^{2}$ is the problem of weaning in Asian infants.

It had been our impression in hospital practice that anaemia is common in Asian children during the second year of life, similar to findings in Glasgow. ${ }^{3}$ The higher prevalence of rickets in this group is well known. As part of the follow up of Asian babies born at this hospital we took the opportunity to establish the prevalence of anaemia and vitamin $\mathrm{D}$ deficiency in this high risk group, to determine the causes of the individual and combined problems, and to assess the effects of these problems on the health of the children.

\section{Patients and methods}

The children studied were born at Sorrento Maternity Hospital, Birmingham. Their mothers had taken part in a study of nutritional supplementation during pregnancy, ${ }^{4}$ and they are the same children described in our study of tuberculin response after bacille Calmette-Guérin vaccine at birth, ${ }^{5}$ apart from four whose mothers declined the invitation for a blood test.

Altogether, 145 children aged 21-23 months were seen by one of us (HG), with the help of a health visitor and interpreter, at one of four child health centres in central Birmingham. One child was found to have coeliac disease and was not included in the study. The following assessments were made.

(a) Dietary history, including duration of time breast fed; age at introduction of cow's milk, solids, and household foods; and whether or not the child was taking vitamin supplements. A rough estimate of the amount of iron in their diet was assessed by allotting a score of $0-4$ for iron content of a food whenever it had been eaten in the past four days - that is, 4 for meat, 2 for each vegetable, 1 for cereals.

(b) Psychomotor development, using the Sheridan developmental sequences. ${ }^{6}$

(c) Anthropometry, including weight in napkin and vest, supine length on a Stadiometer (both expressed as a standard deviation score of the American centre for health statistics), ${ }^{7}$ and subscapular and triceps skinfold thicknesses, using Harpenden calipers.

(d) Clinical examination. 
(e) Haematological investigations, including haemoglobin concentration, red cell indices, white cell count, haemoglobin electrophoresis, serum iron concentration (colourimetric method using ferrozine (Sigma Chemical Company)) and transferrin (radial immunodiffusion) and ferritin (enzyme immunoassay (Abbott Laboratories)) activities. Four children with $\beta$ thalassaemia trait and 25 others had a haemoglobin concentration less than $10 \mathrm{~g} / \mathrm{dl}$ and were recalled to a clinic at the hospital. Of these, 24 (four with the trait and 20 others) reattended, and further investigations included repeat blood counts in all children and blood lead concentrations and serum and red cell folate in 16.

(f) Biochemical measurements of nutritional state, including serum alkaline phosphatase and alkaline ribonuclease activities and zinc and albumin concentrations. Plasma vitamin D (25-hydroxycholecalciferol) was measured in 124 children, 59 boys and 65 girls (competitive protein binding assay based on the method of Preece et $\left.a l^{8}\right)$. As concentrations of plasma vitamin D vary throughout the year, perhaps as much as twofold, it is difficult to set one concentration below which vitamin $\mathrm{D}$ state is considered deficient. For this study a vitamin $\mathrm{D}$ concentration $<10 \mathrm{ng} / \mathrm{ml}$ was taken to be suboptimal and $<5 \mathrm{ng} / \mathrm{ml}$ deficient. Measurements of serum albumin and calcium concentrations were available on the mothers in pregnancy at 28,33 , and 38 weeks' gestation.

The social and ethnic background of the families had previously been documented during the pregnancy. This included religion (Muslim, Sikh, or Hindu); maternal age and educational class (grade 0 : never attended school; grade 1: primary education; grade 2: 6-10 years' secondary education; up to grade 7: British university degree); duration in England; number of occupants in each room; and father's social class (according to Registrar General's classification).

Children with haemoglobin $<10 \mathrm{~g} / \mathrm{dl}$ were given oral treatment with iron $(3 \mathrm{mg}$ elemental iron $/ \mathrm{kg} /$ day as ferrous sulphate) and those who continued follow up were seen at monthly intervals. Treatment was continued for one month after correction of their haemoglobin concentration and mean corpuscular volume. Children who failed to attend were notified to their health visitors and through them to their general practitioners.

\section{Results}

Haematological state at age 22 months. (Table 1) Ten children had $\beta$ or $\alpha$ thalassaemia trait, and one child had coeliac disease (see Methods). Table 1 shows the haematological characteristics of the
Table 1 Haematological characteristics of Asian children aged 22 months (excluding those with thalassaemia trait)

\begin{tabular}{|c|c|c|c|c|}
\hline & \multirow{2}{*}{$\begin{array}{l}\text { No } \\
\text { investi- } \\
\text { gated }\end{array}$} & \multirow{2}{*}{$\begin{array}{l}\text { Mean } \\
\text { (SD) }\end{array}$} & \multicolumn{2}{|l|}{ Abnormal } \\
\hline & & & $\begin{array}{l}\text { Criterion of } \\
\text { abnormality }\end{array}$ & $\begin{array}{l}\text { No } \\
(\%)\end{array}$ \\
\hline $\begin{array}{l}\text { All children } \\
\text { Haemoglobin (g/dl) }\end{array}$ & 134 & $11 \cdot 3(1 \cdot 4)$ & $\begin{array}{l}<11^{*} \\
<10\end{array}$ & $\begin{array}{l}55(31) \\
25(19)\end{array}$ \\
\hline $\begin{array}{l}\text { Serum iron }(\mu \mathrm{mol} / \mathrm{l}) \\
\text { Transferrin }\end{array}$ & 124 & $14.9(6 \cdot 8)$ & $<9^{*}$ & $15(12)$ \\
\hline $\begin{array}{c}\text { saturation (\%) } \\
\text { Mean corpuscular }\end{array}$ & 123 & $15 \cdot 1(8 \cdot 2)$ & $<15^{*}$ & $71(58)$ \\
\hline $\begin{array}{l}\text { volume (fl) } \\
\text { Mean corpuscular }\end{array}$ & 133 & $67.6(8 \cdot 7)$ & $<70 \dagger$ & $68(51)$ \\
\hline $\begin{array}{l}\text { haemoglobin (pg) } \\
\text { Plasma ferritin }(\mathrm{ng} / \mathrm{ml})\end{array}$ & $\begin{array}{r}133 \\
90\end{array}$ & $\begin{array}{r}22 \cdot 2(3 \cdot 7) \\
7 \cdot 4(7 \cdot 2)\end{array}$ & $\begin{array}{l}<24 \ddagger \\
<7 \S\end{array}$ & $\begin{array}{l}77(58) \\
51(57)\end{array}$ \\
\hline $\begin{array}{l}\text { Children with haemoglobin } \\
\text { Serum iron }(\mu \mathrm{mol} / l) \\
\text { Transferrin }\end{array}$ & ${ }_{20}^{<10} \mathrm{~g} / \mathrm{dl}$ & $12 \cdot 7(5 \cdot 4)$ & $<9^{*}$ & $3(15)$ \\
\hline $\begin{array}{l}\text { saturation }(\%) \\
\text { Mean corpuscular }\end{array}$ & 20 & $10 \cdot 7(4 \cdot 3)$ & $<15^{*}$ & $15(75)$ \\
\hline $\begin{array}{l}\text { volume (fl) } \\
\text { Mean corpuscular }\end{array}$ & 20 & $55.9(6.6)$ & $<70 \dagger$ & $19(95)$ \\
\hline haemoglobin (pg) & 20 & $17 \cdot 2(2 \cdot 2)$ & $<24 \ddagger$ & $20(100)$ \\
\hline Plasma ferritin $(\mathrm{ng} / \mathrm{ml})$ & 20 & $3.7(7.8)$ & $<78$ & $18(90)$ \\
\hline $\begin{array}{l}\text { Blood lead }(\mu \mathrm{g} / \mathrm{dl}) \\
\text { Red blood cell }\end{array}$ & 16 & $17 \cdot 5(8 \cdot 3)$ & $>35 \|$ & $\mathbf{0}$ \\
\hline folate $(\mathrm{ng} / \mathrm{ml})$ & 16 & $427 \quad(162)$ & $<100^{*}$ & 0 \\
\hline Serum folate $(\mathrm{ng} / \mathrm{ml})$ & 16 & $10 \cdot 4(3 \cdot 2)$ & $<3^{*}$ & $\mathbf{0}$ \\
\hline
\end{tabular}

"World Health Organisation. ${ }^{9}$

tDallman. ${ }^{10}$

‡Nathan. ${ }^{11}$

§Siimes. ${ }^{12}$

|Department of Health and Social Security. ${ }^{13}$

other 134 children. Anaemia and iron deficiency were common; a fifth of children had a haemoglobin concentration $<10 \mathrm{~g} / \mathrm{dl}$. Commonly accepted indices of iron deficiency-for example, microcytosis, low ferritin activity, and low transferrin saturationwere found in more than half of the children.

Vitamin D state at age 22 months. (Fig. 1) Plasma vitamin $\mathrm{D}$ concentration in the 124 children ranged from $2 \cdot 1$ to $39 \mathrm{ng} / \mathrm{ml}$ with a mean (SD) of $12 \cdot 7(6 \cdot 5)$ $\mathrm{ng} / \mathrm{ml}$. Boys had significantly higher concentrations than girls $(14.3(6.8) v 11.5(6.0) \mathrm{ng} / \mathrm{ml}$, respectively, $\mathrm{p}<0.05)$. There were 49 children $(40 \%)$ with vitamin $\mathrm{D}$ concentrations under $10 \mathrm{ng} / \mathrm{ml}$ and seven $(6 \%)$ with concentrations under $5 \mathrm{ng} / \mathrm{ml}$.

The 92 children taking vitamin supplements had higher vitamin D concentrations than the 32 unsupplemented ones $(13.1(6.1) v 11.4(7.0) \mathrm{ng} / \mathrm{ml}$, not significant). The well described seasonal variation in vitamin D was noted in the unsupplemented group. This seasonal variation was minimal in the supplemented children, who had higher vitamin D concentrations than the unsupplemented children in winter but had no advantage in summer. 


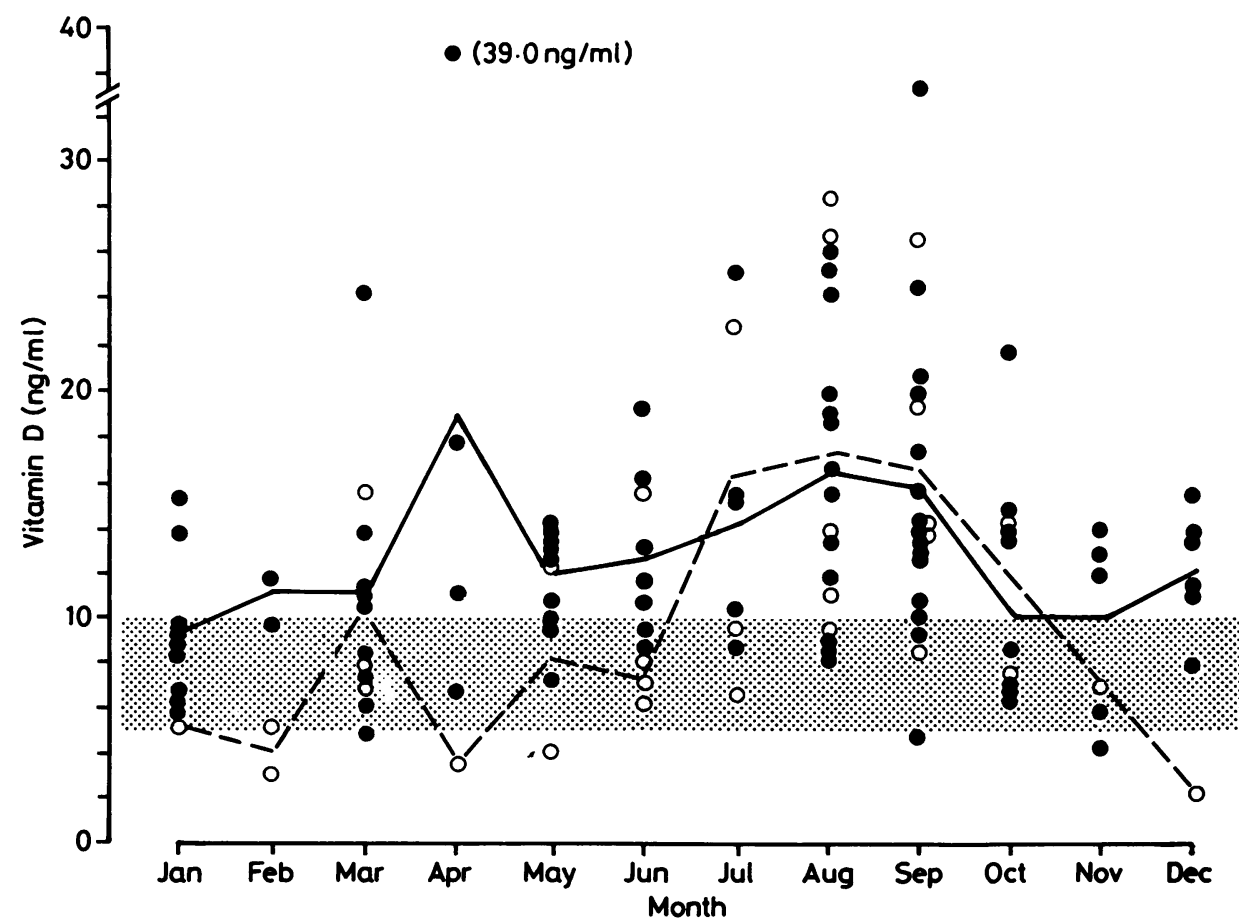

Fig. 1 Plasma vitamin D (mean and individual values) in Asian toddlers according to seasonal variation and vitamin supplementation. $-\quad-$ Vitamin supplemented children; $\bigcirc--\bigcirc=$ unsupplemented children . Plasma vitamin $D<10 \mathrm{ng} / \mathrm{ml}=$ suboptimal (shaded area), $<5 \mathrm{ng} / \mathrm{ml}=$ deficient.

Association of anaemia and poor vitamin $D$ state. (Fig. 2) Twenty four children had both haemoglobin $<11 \mathrm{~g} / \mathrm{dl}$ and plasma vitamin $\mathrm{D}<10 \mathrm{ng} / \mathrm{ml}$.

Children with plasma vitamin $\mathrm{D}<10 \mathrm{ng} / \mathrm{ml}$ had significantly lower haemoglobin and serum iron concentrations. Mean values for mean corpuscular volume, transferrin saturation, and ferritin activity were also lower but not significantly so.

Social characteristics. (Table 2) More Muslim

Table 2 Social characteristics of Asian children at 22 months. Values are No or mean (SD)

\begin{tabular}{|c|c|c|c|c|c|c|}
\hline & \multicolumn{6}{|c|}{ Haemoglobin and vitamin $D$ concentrations } \\
\hline & \multicolumn{3}{|c|}{ Haemoglobin $(g / d l)$} & \multicolumn{2}{|c|}{ Vitamin $D(n g / m l)$} & \multirow{2}{*}{$\begin{array}{l}\text { Haemoglobin }<11 \mathrm{~g} / \mathrm{dl} \\
\text { and vitamin } \\
D<10 \mathrm{ng} / \mathrm{ml}\end{array}$} \\
\hline & $\geqslant 11$ & $<11$ & $<10$ & $\geqslant 10$ & $<10$ & \\
\hline \multicolumn{7}{|l|}{ Sex: } \\
\hline Male & 46 & 28 & 13 & 42 & 17 & 6 \\
\hline \multirow{2}{*}{\multicolumn{7}{|c|}{ Religion: }} \\
\hline & & & & & & \\
\hline Muslim & 45 & $44 \dagger$ & $24+t$ & 41 & 34 & $21^{* *}$ \\
\hline Non-Muslim $\ddagger$ & 38 & 17 & 5 & 34 & 15 & 3 \\
\hline No of years in England & $5.8(6)$ & $4.9(5)$ & $4 \cdot 1 \quad(5)$ & $5 \cdot 4(5)$ & $4.5(5)$ & $3 \cdot 2(3)^{* *}$ \\
\hline Occupants per room§ & $1 \cdot 2(0.5)$ & $1.5(0.9)^{*}$ & $1.4(0.8)$ & $1.3(0.8)$ & $1.3(0.9)$ & $1.3(0.8)$ \\
\hline Father's social class & $3.4(0.9)$ & $3.7(1)$ & $3.9(1)^{*}$ & $3.7(0.8)$ & $3.5(0.9)$ & $4.0(1)^{*}$ \\
\hline Mother's educational class & $2.6(1.6)$ & $2 \cdot 1(2)$ & $1.6(1.4)^{* *}$ & $2.5(1.7)$ & $2 \cdot 1(1 \cdot 7)$ & $1.8(2)$ \\
\hline No of previous births & $1.2(1.6)$ & $1.5(1.7)$ & $1.7(2)$ & $1.2(1.3)$ & $1.3(1.5)$ & $1.7(1.7)$ \\
\hline
\end{tabular}

Mean significantly different from children with haemoglobin $\geqslant 11 \mathrm{~g}$ or vitamin $\mathrm{D} \geqslant 10 \mathrm{ng} / \mathrm{ml}-t$ test: ${ }^{*} \mathrm{p}<0 \cdot 05,{ }^{* *} \mathrm{p}<0 \cdot 01$.

Proportion of anaemic Muslim and female vitamin D deficient children greater than non-Muslims and male groups, respectively- $x^{2}$ test: $\dagger \mathrm{p}<0.05$, + tp $<0.01$.

$\ddagger$ Prevalence of anaemia and of vitamin D deficiency was similar in Sikhs and Hindus.

$\$$ More than 1.5 occupants/room constitutes overcrowding. 


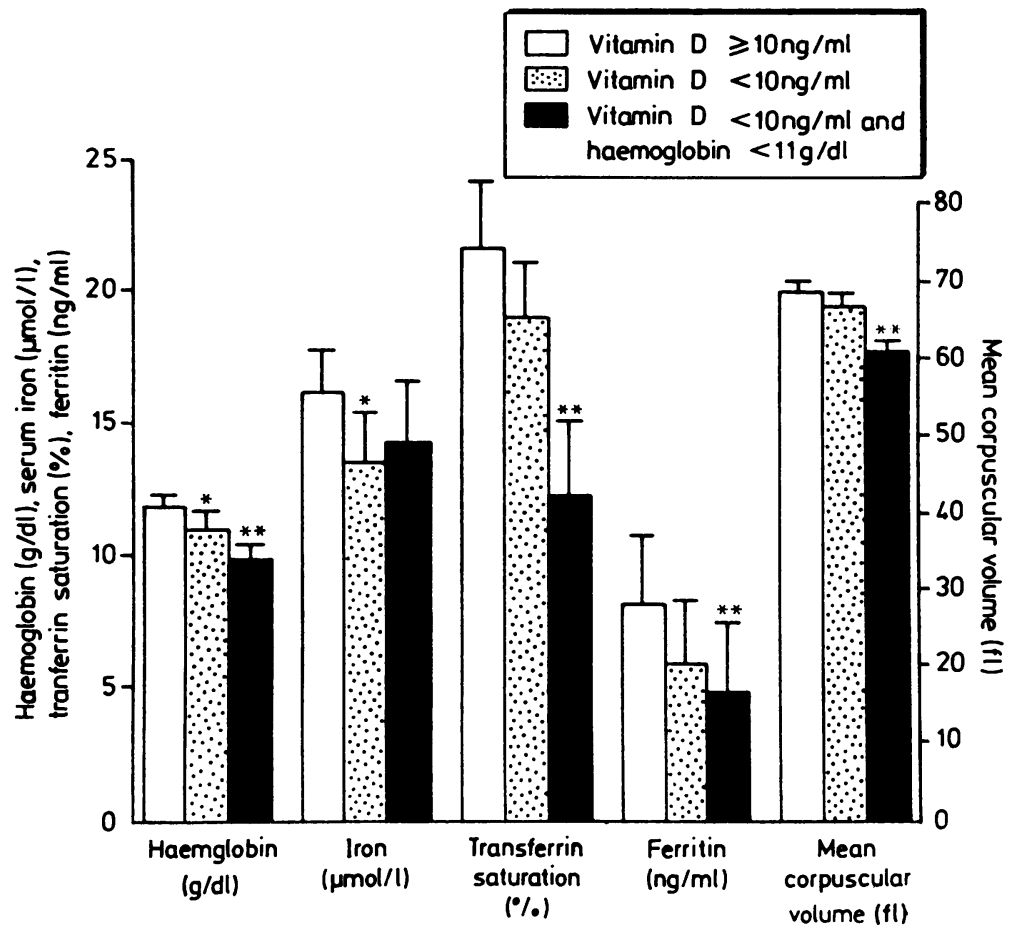

Fig. 2 Relations between haematological characteristics and vitamin D state in Asian children aged 22 months (2SE).

Results significantly different from children with vitamin $\mathrm{D} \geqslant 10 \mathrm{ng} / \mathrm{ml}:{ }^{*} \mathrm{p}<0 \cdot 05,{ }^{* *} \mathrm{p}<0.01$.

children were anaemic. The families of children with low haemoglobin and vitamin D concentrations tended to be larger and live in more crowded conditions; they had been in England for a shorter time and were of poorer social and maternal educational class, but not all of these differences achieved significance.
Nutritional characteristics. (Table 3) Both the children with anaemia and those with a low vitamin D concentration were fatter at birth and at 22 months and had lower plasma alkaline ribonuclease activity. Serum concentrations of albumin and zinc were similar in all groups.

No dietary differences were detected. Comparing

Table 3 Nutritional characteristics of Asian children at 22 months. Values are mean (SD)

\begin{tabular}{|c|c|c|c|c|c|c|}
\hline & \multicolumn{6}{|c|}{ Haemoglobin and vitamin $D$ concentrations } \\
\hline & \multicolumn{3}{|c|}{ Haemoglobin $(\mathrm{g} / \mathrm{dl})$} & \multicolumn{2}{|c|}{ Vitamin $D(n g / m l)$} & \multirow{2}{*}{$\begin{array}{l}\text { Haemoglobin }<11 \mathrm{~g} / \mathrm{dl} \\
\text { and vitamin } \\
D<10 \mathrm{ng} / \mathrm{ml}\end{array}$} \\
\hline & $\geqslant 11$ & $<11$ & $<10$ & $\geqslant 10$ & $<10$ & \\
\hline \multicolumn{7}{|l|}{ Birth: } \\
\hline $\begin{array}{l}\text { Weight (kg) } \\
\text { Subscapular skinfold }\end{array}$ & $3.07(0.5)$ & $3.15(0.4)$ & $3 \cdot 14(0 \cdot 6)$ & $3.03(0.4)$ & $3 \cdot 15(0 \cdot 4)$ & $3 \cdot 12(0 \cdot 4)$ \\
\hline $\begin{array}{l}\text { thickness at birth (mm) } \\
\text { At } 22 \text { months: }\end{array}$ & $3.8(0.9)$ & $4 \cdot 1(1)^{*}$ & $4 \cdot 2(1)^{*}$ & $4 \cdot 3(0 \cdot 5)$ & $4 \cdot 5(1 \cdot 1)$ & $4 \cdot 4(0 \cdot 8)^{* *}$ \\
\hline $\begin{array}{l}\text { Weight standard deviation } \\
\text { score }\end{array}$ & $+0 \cdot 1(0 \cdot 2)$ & $+0.3(0.9)$ & $+0 \cdot 1(0 \cdot 7)$ & $+0.05(1.0)$ & $+0.2(1.0)$ & $+0.2(0.9)$ \\
\hline $\begin{array}{l}\text { Subscapular skinfold } \\
\text { thickness }(\mathrm{mm})\end{array}$ & $6.3(1.5)$ & $6.4(1.3)$ & $6 \cdot 5(1 \cdot 3)$ & $6 \cdot 2(1 \cdot 7)$ & $6.9(1.4)$ & $7.0(1 \cdot 1)^{*}$ \\
\hline $\begin{array}{l}\text { Alkaline ribonuclease } \\
(\mu / 1)\end{array}$ & $520(80)$ & $509(92)$ & $513(97)$ & $539(72)$ & $494(78)^{* * *}$ & $480(73)^{*}$ \\
\hline Albumin $(g / l)$ & $43(4)$ & $43(3)$ & $43(4)$ & $44(3)$ & $\begin{array}{l}494(10) \\
44(2)\end{array}$ & $44(3)$ \\
\hline Zinc $(\mu \mathrm{mol} / \mathrm{l})$ & $10 \cdot 0(2 \cdot 1)$ & $9.7(1 \cdot 3)$ & $10 \cdot 2(1 \cdot 3)$ & $9.8(1.4)$ & $10 \cdot 1(1 \cdot 5)$ & $10 \cdot 2^{(1 \cdot 5)}$ \\
\hline
\end{tabular}

Mean significantly different from children with haemoglobin $\geqslant 11 \mathrm{~g}$ or vitamin $\mathrm{D} \geqslant 10 \mathrm{ng} / \mathrm{ml} t$ test: ${ }^{*} \mathrm{p}<0 \cdot 05,{ }^{* *} \mathrm{p}<0 \cdot 01$. 
the groups with and without anaemia, there were no significant differences in mean duration of breast feeding ( $7 v 6.4$ weeks), age of introduction of pasteurised cow's milk (27 v 31 weeks), age of introduction of solid foods ( $25 v 23$ weeks), and iron score of diet in previous four days (45 v 44).

Psychomotor development at 22 months. Children with haemoglobin $<11 \mathrm{~g} / \mathrm{dl}$ showed slight but consistent delay in psychomotor development compared with the children without anaemia. The differences reached significance for fine motor and social development (haemoglobin $<11 \mathrm{~g} v$ haemoglobin $>11 \mathrm{~g}$ (mean (SD)) (months): fine motor 20.6 $(1.6)$ v $21.5(1.5), \mathrm{p}<0.05$; social $20.6(1.6) v 21.4$ $(1 \cdot 4), p<0 \cdot 01)$. These differences were not observed when children with adequate and low vitamin D concentrations were compared.

\section{Discussion}

Anaemia and poor vitamin D state occurred commonly in these Asian toddlers. Two fifths had low vitamin $\mathrm{D}$, two fifths were anaemic, and one fifth had both features. This study was not planned as a random sample of the local population of Asian toddlers. The sample consisted only of children born at Sorrento Maternity Hospital whose parents were sufficiently motivated to bring them to child health clinics for follow up. We suspect that some children who did not attend the clinic had less motivated parents and were more liable to be anaemic or vitamin $\mathrm{D}$ deficient. What was the cause and effects of these problems and what, if anything, should be done about them?

\section{Causes.}

\section{Anaemia}

Investigations suggested iron deficiency as the cause of the anaemia (low mean corpuscular volume, transferrin saturation, and ferritin activity). We consider this to be dietary in origin. Nevertheless, we could detect no dietary differences between the groups with and without anaemia. This probably reflects the crude methods used for dietary assessment, but both groups had diets suggesting a low iron intake- that is, early introduction of pasteurised milk, fairly late introduction of weaning foods, and infrequent consumption of iron containing foods. Hookworm ova were not sought, but all children were born in this country and no hookworm ova were found in Asians in Glasgow. ${ }^{14}$ Many of the children lived in poor inner urban housing where lead poisoning may have been expected, though only one child had a high bood lead concentration.
It was the custom in many households to simmer vegetables for long periods, but no cases of folate deficiency were found. Anaemia was more common in Muslims, yet they are meat eaters.

\section{Vitamin $D$ deficiency}

Sunlight was found to be more important than diet in maintaining vitamin $\mathrm{D}$ concentrations in white children in neighbouring Dudley. ${ }^{15}$ The rise in vitamin D during the summer months in our study, however, was modest and much below that seen in both Dudley ${ }^{15}$ and Edinburgh. ${ }^{16}$ Recorded use of dietary vitamin supplements had almost as much effect as the season in our study. It seems that for these children dietary supplementation can be almost as useful as our summer.

\section{Association of the two deficiencies}

There was a significant association, not a mere overlap, of the two deficiencies. Children with a low vitamin D concentration had lower haemoglobin and serum iron concentrations. This was particularly noticeable in winter when half of those with low vitamin $\mathrm{D}$ concentration were anaemic compared with none of those with an adequate vitamin D concentration. Both deficiencies were associated with evidence of an underprivileged environmentmore crowded living conditions and poorer social class and maternal education. This association of the two deficiencies is not, however, just a sign of a generally poor nutritional state. The deficient children had no evidence of protein energy or zinc malnutrition. Indeed, their protein energy state was slightly better than the sufficient children in that they were a little fatter and had lower plasma activities of alkaline ribonuclease.

Effects. There was no evidence that the children with anaemia or those with poor vitamin D state suffered more ill health, nor was their growth compromised.

Psychomotor development was significantly delayed in the children with anaemia. These observations were all made by the same observer (HG) before the haemoglobin values were known, so we do not consider there is any possibility of bias. The investigation was not designed, however, to study this problem nor did the psychomotor assessments have the rigour of one of the formal measurements (such as the Denver or Griffiths scales). We therefore draw no conclusions from this but are planning an intervention study.

Detection and prevention. Clearly, monitoring of growth and other simple methods of child health 
surveillance would not detect these children; a haemoglobin determination is necessary.

If these continuing deficiencies of iron and vitamin D are to be prevented would dietary advice alone be enough? A substantial proportion of the iron and vitamin D intake of white English toddlers comes from fortified foods and supplements, ${ }^{17}$ so we suspect that some reliance on fortification or supplementation, or both, will be necessary. This study suggests that a combined approach to prophylaxis against iron and vitamin $\mathrm{D}$ deficiency should be considered. There are three possible combined strategies.

(a) The use of an infant formula or follow up milk containing iron and vitamin D. This would have to continue throughout early childhood as these children were 22 months old.

(b) The addition of iron to Department of Health and Social Security vitamin drops. Commercial equivalents are available, but the relative availability of the iron and continued potency of vitamin D would need further assessment. Even if this was adopted, our vitamin D results suggest that reliance on regular small supplements, particularly in girls, is not effective, despite the efforts of the Asian rickets prevention campaign. This is probably because of underexposure to sunlight. In our study, however, this supplementation had as much effect as the season. In the short term it might be easier to ensure vitamin D supplementation than alter patterns of behaviour.

(c) Some years ago the fortification of baby cereals with both iron and vitamin D was a method of combined prophylaxis, but vitamin D was then considerably reduced after the epidemic of hypercalcaemia. Should this be reviewed? Opinion varies on the value of iron fortification of cereals. While the American Academy of Pediatrics commends the use of iron fortified cereal for prophylaxis ${ }^{18}$ the European Society of Pediatric Gastroenterology and Nutrition comments that 'the addition of iron to cereals is not a reliable method of enriching the diet with iron' ${ }^{19}$

These possible strategies need to be assessed and compared. In the meantime, however, we suspect that option (a)-that is, the continued use of an infant formula or a follow up milk-is likely to be the most effective, and this is what we advise individual mothers. There is evidence of good iron absorption from iron and vitamin $C$ fortified infant formulas. Vitamin D concentrations and plasma ferritin activities are rarely low in infants receiving such formulas. ${ }^{20} 21$
References

${ }^{1}$ Oppe TE, Arneil GC, Creery RDG, et al. Present day practice in infant feeding. London: HMSO, 1974. (Report on Health and Social Subjects No 9.)

2 Oppe TE, Arneil GC, Davies DP, et al. Present day practice in infant feeding. London: HMSO, 1980:37. (Report on Health and Social Subjects No 20.)

${ }^{3}$ Goel KM, Logan RW, House F, et al. The prevalence of haemoglobinopathies, nutritional iron and folate deficiencies in native and immigrant children in Glasgow. Health Bull (Edinb) 1978;36:176-82.

4 Viegas OAC, Scott PH, Cole TJ, Mansfield HN, Wharton P, Wharton BA. Dietary protein energy supplementation of pregnant Asian mothers at Sorrento, Birmingham. I: Unselective during second and third trimesters. II: Selective during third trimester. Br Med J 1982;285:589-95.

5 Grindulis H, Baynham MID, Scott PH, Thompson RA, Wharton BA. Tuberculin response two years after BCG vaccination at birth. Arch Dis Child 1984;59:614-9.

6 Sheridan M. Childrens developmental progress. Windsor: NFER, 1978:1-55.

7 National Centre for Health Statistics. NCHS Growth Charts. Vital Health Stat (11).

${ }^{8}$ Preece MA, O'Riordan JLH, Lawson DEM, Kudicek E. A competitive protein-binding assay for 25-hydroxycholecalciferol and 25-hydroxyergocalciferol in serum. Clin Chim Acta 1974;54:235-42.

9 World Health Organisation. Nutritional anaemias. WHO Tech Rep Ser 1972;No 503.

10 Dallman PR, Siimes MA. Percentile curves for haemoglobin and red cell volume in infancy and childhood. $J$ Pediatr 1979;94:26-31.

11 Nathan DG, Oski FA. Hematology of infancy and childhood. 2nd ed. Philadelphia: W B Saunders, 1981:1555.

12 Siimes MA, Addiego JE, Dallman PR. Ferritin in serume diagnosis of iron deficiency and iron overload in infants and children. Blood 1974;43:581-90.

13 Department of Health and Social Security. Lead and health. The Report of the DHSS Working Party on Lead in the Environment. London: HMSO, 1980.

14 Goel KM, Shanks RA, McAllister TA, Follett EAC. Prevalence of intestinal parasitic infestations salmonellosis, brucellosis, tuberculosis and hepatitis $B$ among immigrant children in Glasgow. Br Med J 1977;i:676-9.

15 Poskitt EME, Cole TJ, Lawson DEM. Diet, sunlight, and 25-hydroxy vitamin D in healthy children and adults. Br Med J 1979;i:221-3.

16 O'Hare AE, Uttley WS, Belton NR, Westwood A, Levin SD, Anderson F. Persisting vitamin D deficiency in the Asian adolescent. Arch Dis Child 1984;59:766-70.

17 Department of Health and Social Security. A nutritional survey of pre-school children 1967/68. London: HMSO, 1975: $74,79,86,89$. (Report on Health and Social Subjects No 10.)

18 American Academy of Pediatrics. Committee on nutrition from supplementation for infants. Pediatrics 1976;58:765-8.

19 European Society of Pediatric Gastroenterology and Nutrition. Committee on Nutrition. Guidelines on infant nutrition. II: Recommendations for the composition of follow-up formulas and beikost. Acta Paediatr Scand 1981;287(Suppl):17.

20 Dallman PR. Iron deficiency in the weanling: a nutritional problem on the way to resolution In: Wharton BA, ed. Food for the weanling. Acta Paediatr Scand 1986;323(Suppl):59-66.

21 Belton NR. Rickets-not only the "English disease" In: Wharton BA, ed. Food for the weanling. Acta Paediatr Scand 1986;323(Suppl):68-75.

Correspondence to Dr B A Wharton, Department of Maternal and Child Health, Sorrento Maternity Hospital, Wake Green Road, Moseley, Birmingham B13 9HE, England.

Received 23 May 1986 